Les littératures de langue française à l'heure de la mondialisation. Lise Gauvin (org). Montreal: Constantes/Académie des Lettres du Québec/Hurtubise, 2010.

\title{
UMA VISÃO ATUAL DAS LITERATURAS DE LÍNGUA FRANCESA
}

O livro Les littératures de langue française à l'heure de la mondialisation, organizado por Lise Gauvin, contém textos apresentados no colóquio anual da Académie des Lettres du Québec, feito em parceria com a Bibliothèque et Archives nationales du Québec. O evento foi realizado em Montreal, no dia 17 de outubro de 2008, simultaneamente à reunião de cúpula da OIT (Organização Internacional da Francofonia), que aconteceu na cidade de Quebec. O tema em torno do qual girou o colóquio foi o Manifeste pour une littérature-monde en français, publicado no jornal Le Monde em março de 2007. Este livro assinala a posição crítica dos quebequenses em relação ao Manifesto e a favor da francofonia literária, embora reconheça o ranço colonial que subsiste no termo francofonia, tal como usado no terreno da política internacional.

Lise Gauvin, professora da Universidade de Montreal, que era então presidente da Academia, fala de "malentendido francófono", visando atacar sobretudo as instituiçóes literárias francesas: o paradoxo apontado por ela é que a França constitui o centro da francofonia sem querer fazer parte dela. No artigo "La francophonie littéraire, un espace encore à créer", ela comenta o sentido e as repercussōes do Manifeste pour une littérature-monde en français, que tinha a pretensão de marcar a morte da francofonia. Aliás, curiosamente, o Manifesto aqui aparece publicado pela primeira vez em livro, apesar de seus mentores, Michel Le Bris e Jean Rouaud, terem dado a público, pela Gallimard, Pour une littérature-monde poucos meses depois (2007), com textos de alguns escritores, signatários ou não do Manifesto, mas sem o Manifesto.

Associando o termo littérature-monde com World Literature, Lise Gauvin diz temer que esta noção seja um avatar disfarçado da ideia de universal imposto pelas culturas dominantes para garantir sua hegemonia. Ela retoma uma noção, já desenvolvida por ela há alguns anos, notadamente no livro Langagement (Boréal, 2000), de que o escritor de língua francesa desenvolve uma superconsciên- 
cia linguística (surconscience linguistique) pelo fato de conviver com mais de uma língua, seja com o inglês no caso do Quebec, com o crioulo nas Antilhas, com o árabe no Magreb, com línguas étnicas na África subsaariana. "Condenado a pensar a língua, a encontrar sua própria língua de escrita num contexto multilingue, este autor deve inventar novas formas capazes de fazer ouvir a complexidade de suas pertenças. Deve assim, sem renunciar a certos patamares de legibilidade, compor com a opacidade das culturas singulares no imaginário da língua" (p. 28). A hibridação provocada pelo contato com outra língua contribui fortemente para processos de desterritorialização do francês e para transformações da forma romancesca nas literaturas francófonas. Inspirada na poética de Fernando Pessoa, Gauvin considera que se trata de "literaturas do desassossego" (littératures de l'intranquillité), em contraposição ao conceito de "literatura menor", cunhado por Gilles Deleuze e Jacques Guattari em seu livro sobre Kafka, que muitos críticos associaram a essas literaturas. Ela observa também que a forma do romance foi desestabilizada e reinventada por autores caribenhos e latino-americanos, ao estabelecerem fronteiras porosas entre a realidade e a ficção, entre os diversos níveis de ficção, interpelando o leitor e obrigando-o a uma constante reavaliação do pacto enunciativo (p. 25).

No belo depoimento de J.M.G. Le Clézio, "Le français, beaucoup plus qu'une langue", primeira conferência proferida por ele após o anúncio do Prêmio Nobel que lhe foi conferido em 2008, ele evoca suas lembranças de infância, época formadora de seu imaginário. Considera que a história das línguas é tão injusta e imprevisível quanto a história dos povos já que à dominação de umas corresponde o enfraquecimento - quiçá o desaparecimento - de outras. Ele reitera aquilo que Roland Barthes já dizia, que as línguas não são inocentes, elas têm uma história política. No caso do francês, trata-se de uma língua que tem uma situação ambígua: ameaçada no Quebec, ela é, por isto mesmo, fortemente reivindicada; já em antigas colônias da América e da África, ela pode ser vista como uma língua de dominação, impregnada de violência e de racismo. Ele avalia positivamente o estatuto do francês no mundo contemporâneo, afirmando: "O francês é muito mais que uma língua. É um lugar de trocas e encontros. Suas fronteiras se dissolveram na totalidade do mundo, o que não significa um desenraizamento nem uma vulnerabilidade, mas ao contrário maior liberdade, uma audácia e uma ressonância novas" (p. 41). 
Olivier Kemeid, em "Une résistance classique”, manifesta-se também contrário a alguns pontos levantados pelo Manifesto, assinalando que a causa principal da recusa dos autores francófonos na França estaria antes no uso particular que eles fazem da língua francesa. Desde Richelieu, o francês tornou-se uma língua rígida, clássica, que não admite barroquismos; assim, os franceses podem apreciar o barroco praticado por escritores latino-americanos, traduzidos em francês, mas não aceitam as rupturas praticadas no nível linguístico por aqueles que escrevem em francês.

Em "La littérature-monde au détour de la transculturalité?", Dominique D. Fisher considera que a literatura do Quebec não carrega o peso da história colonial francesa nem as pressões das instituições literárias francesas, o lhe confere autonomia. Além disto, desde os anos 1980 ela se inscreve numa geopolítica transnacional e transcultural, com o aporte dos numerosos escritores vindos dos quatro cantos do mundo.

Dany Laferrière, que deixou o Haiti em 1976 devido à ditadura de Baby Doc e se radicou no Quebec, critica a etiqueta usada pela crítica quebequense que o classifica como escritor exilado ou imigrado (écrivain exilé, écrivain immigré), afirmando que o escritor não escreve porque é exilado ou porque emigrou. Aliás, em outros textos, Laferrière recusa outras apelações, tais como escritor francófono ou antilhano, declarando-se, antes, escritor americano. Provocadoramente, ele publicou um romance intitulado Je suis un écrivain japonais em 2008.

Dois textos - um do crítico quebequense Paul Chamberland, e outro, do cineasta Jean-Daniel Lafond - são depoimentos sobre Aimé Césaire, sua vida e sua obra. Durante o colóquio de 2008, foi projetado o filme La manière nègre ou Aimé Césaire, chemin faisant, realizado por Lafond.

Além destes, o livro reúne artigos de outros escritores e críticos do Quebec, como Lise Bissonnette, Madeleine Gagnon, Vénus Khoury-Ghata, Monique LaRue, Joël Des Rosiers e Gilles Pellerin. No final, aparece o Manifesto Pour une "littérature-monde" en français, que foi assinado por 44 escritores, entre eles Edouard Glissant, J.M.G. Le Clézio, Dany Laferrière, Nancy Huston, Jacques Godbout, Maryse Condé e Alain Mabanckou. 